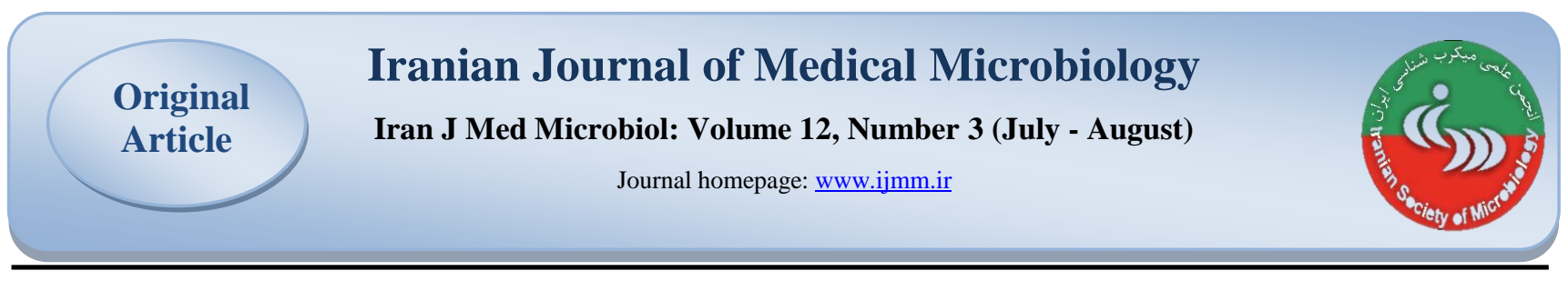

\title{
Protective Effect of Egg Yolk Immunoglobulin (IgY) Against Aflatoxin on Blood Parameters, Ileum Morphometry and Hepatocytes' Histopathology of Broiler Chickens Fed Aflatoxin B1
}

\author{
Ali Nakhaei ${ }^{1}$ Nazar Afzali ${ }^{1}$, Seyyed Javad Hosseini Vashan ${ }^{1}$, Mohammad Amir Karimi Torshizi ${ }^{2}$ \\ 1. Department of Animal Sciences, Faculty of Agriculture, University of Birjand, Birjand, Iran \\ 2. Department of Animal Sciences, Faculty of Agriculture, University of Tarbiyat modares, Tehran, Iran
}

\section{Article Information}

\section{Article history:}

Received: 2018/07/01

Accepted: 2018/08/01

Available online: 2018/10/11

Article Subject:

Food Microbiology

IJMM 2018; 12(3): 199-207

Corresponding author:

\section{Nazar Afzali}

Department of Animal Sciences,

Faculty of Agriculture,

University of Birjand, Birjand,

Iran

Tel: 09151612157

Email:

nafzali@birjand.ac.ir

\author{
Use your device to scan \\ and read the article online
}

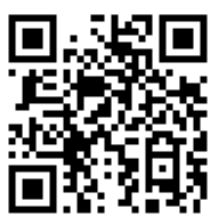

\section{Abstract}

Background and Aims: The aim of this study was to evaluate the protective effect of specific egg yolk immunoglobulin ( $\operatorname{IgY}$ ) against aflatoxin on reducing the defects of aflatoxin by adding to the drinking water of 192 day Ross 308 broiler chickens from 1 to 42 days old.

Materials and Methods: The experiment was based on a completely randomized design with 6 treatments, 4 replications, and 8 observations (chicks). First egg yolks were immunized against aflatoxin by injecting aflatoxin-BSA conjugate to laying hens. Also extracted immunoglobulin with 1 and 0.5 percent /volume concentration was added to broilers' drinking water. The experimental treatments were: 1) control (without any additives); 2) ration contaminated with $1 \mathrm{mg} \mathrm{kg}^{-1}$ aflatoxin B1 (negative control treatment); 3) negative control + $0.5 \%(\mathrm{~V} / \mathrm{V})$ immunized yolk against $\left.\mathrm{AFB}_{1}, 4\right)$ negative control $+0.5 \%(\mathrm{~V} / \mathrm{V})$ unimmunized yolk against $\left.\mathrm{AFB}_{1} ; 5\right)$ negative control $+1 \%(\mathrm{~V} / \mathrm{V})$ immunized yolk against $\mathrm{AFB}_{1}$ and 6 ) negative control $+1 \%(\mathrm{~V} / \mathrm{V})$ unimmunized yolk against $\mathrm{AFB}_{1}$.

Results: Using aflatoxin contaminated diet significantly increased serum cholesterol, and decreased serum total protein and albumin concentration $(P<0.05)$. Also, histopathologic lesions observed in the liver. Adding $1 \%(\mathrm{~V} / \mathrm{V})$ of immunized egg yolk to the drinking water (treatment $5)$ reduced serum cholesterol and increased total protein concentration compared to treatment 2 $(P<0.05)$. The length and width of the villi and the villi surface area of chicks receiving treatment 5 were higher than treatment $2(P<0.05)$. Liver tissue in chicken receiving treatment 3 and 5 , was almost normal and few changes were observed in hepatocytes.

Conclusions: The results indicate that specific $\operatorname{IgY}$ against $\mathrm{AFB}_{1}$ can be effective in reducing the defects of experimental aflatoxicosis as a detoxification agent.

Keywords: Aflatoxin $\mathrm{B}_{1}$, Blood parameters, Specific immunoglobulin

Copyright @ 2018 Iranian Journal of Medical Microbiology. All rights reserved.

How to cite this article:

Nakhaei A, Afzali N, Hosseini Vashan S J, Karimi Torshizi M A. Protective Effect of Egg Yolk Immunoglobulin (IgY) Against Aflatoxin on Blood Parameters, Ileum Morphometry and Hepatocytes' Histopathology of Broiler Chickens Fed Aflatoxin B1. Iran J Med Microbiol. 2018; 12 (3) :199-207 


\title{
بررسى اثر محافظتى ايمنوكلوبولين اختصاصى زردهُ تخممرغ (IgY) عليه آخلاتوكسين بر فراسنجهاى خونى، مورفومترى ايلئوم و هيستوياتولوزى سلولهاى كبد جوجههاى كوشتى \\ Bغ تغيهشيده با آنلاتوكسين
}

\author{
على نخعى'، نظر افضلى'، سيد جواد حسينى واشان'، محمدامير كريمى ترشيزى'
}

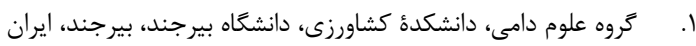

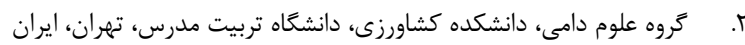

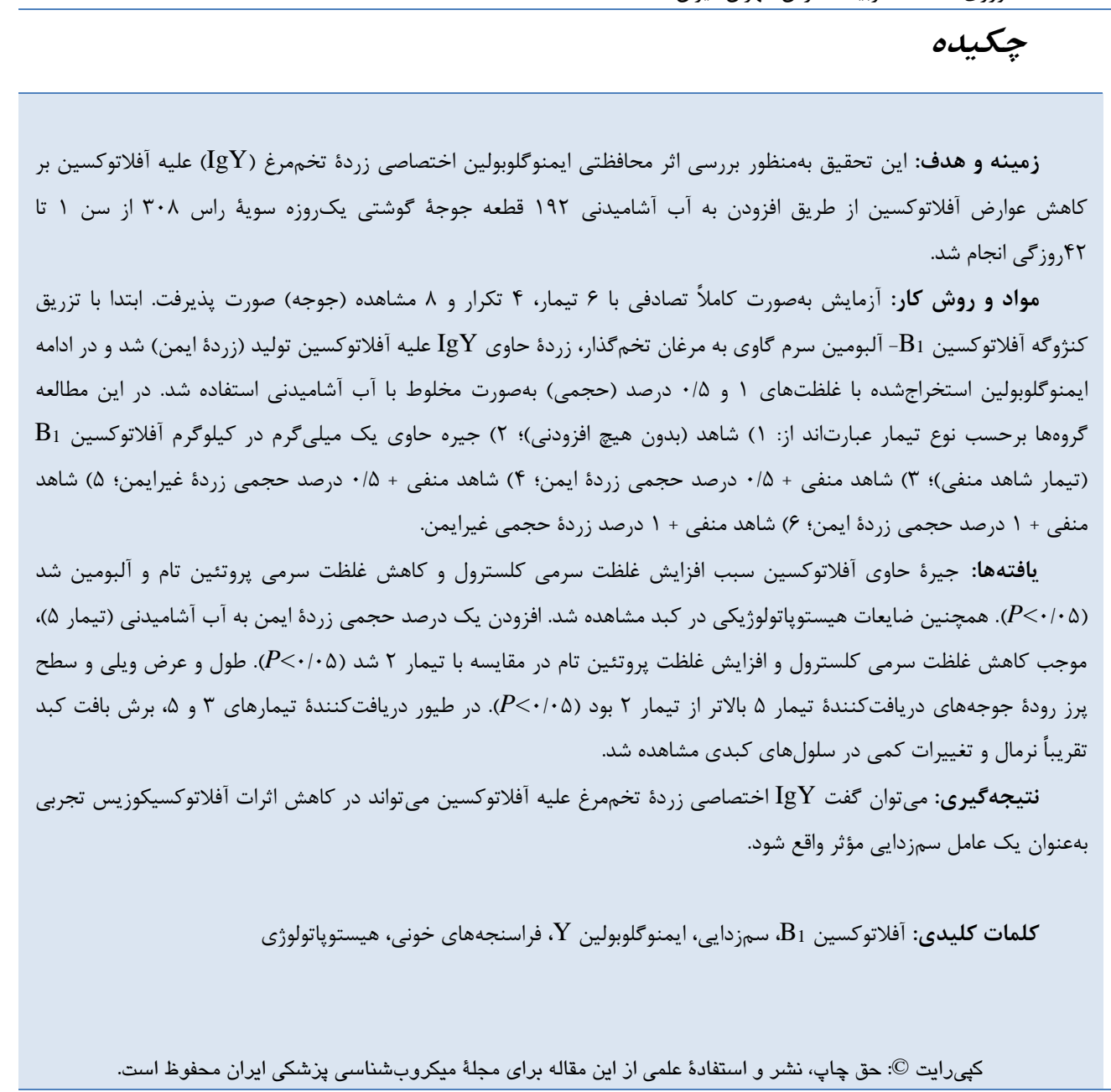

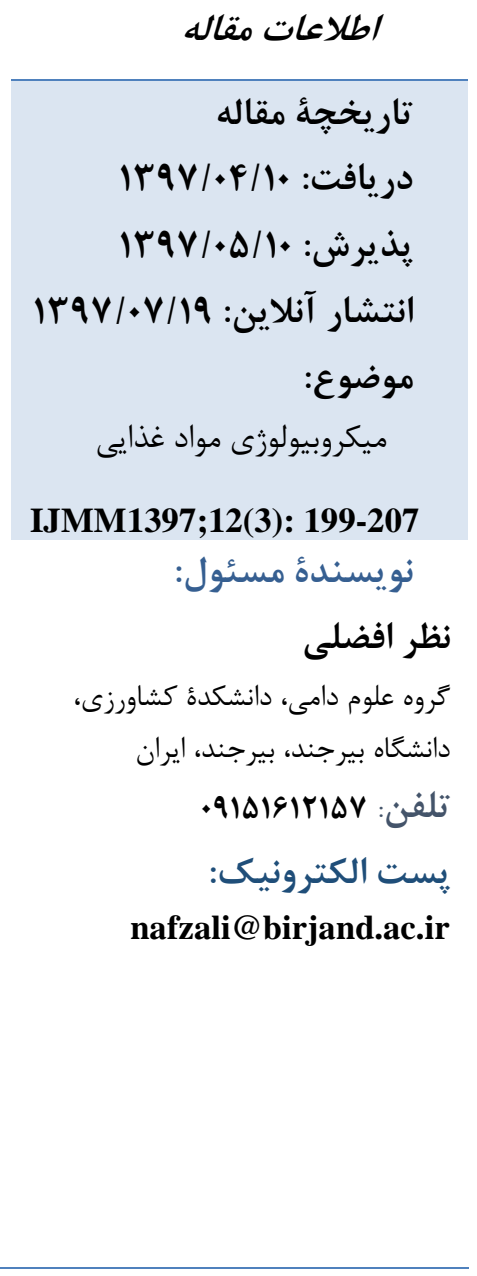

تاكنون روشهاى بيولوزيكى، شيميايى و فيزيكى متعددى

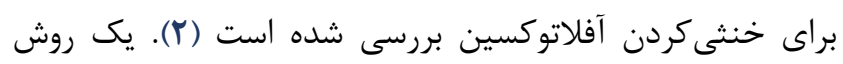
بهكارگيرى مواد جاذب در جيره غذايى است كه با آفلاتوكسينها ييوند ايجاد كرده و جذب آنها را در دستخاه گَوارش كاهش مى مدهد (ז). اما محدوديتهاى روش هاى فيزيكى و شيميايى محققان را به
آفلاتوكسين B آفلاتوكسين از بين انواع آفلاتوكسينهاى شناختهشده (B. و B2 است كه موجب مهار سنتز DNA DNA و كاهش سنتز يروتئين و حساسيت نسبت به استرسهاى ميكروبى و محيطى

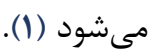




\section{توليد سم}

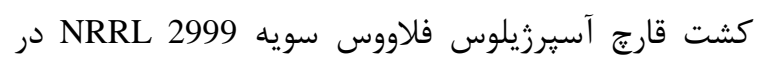

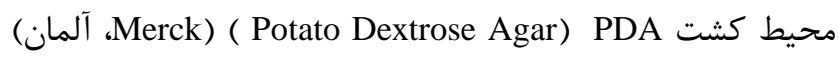

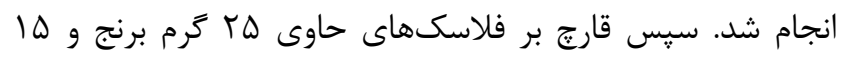

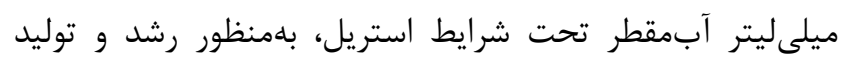

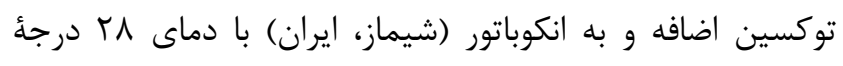

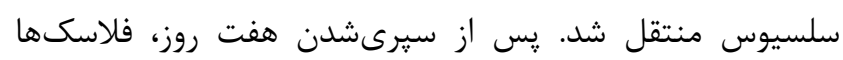

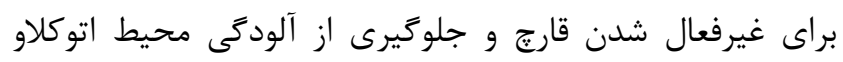

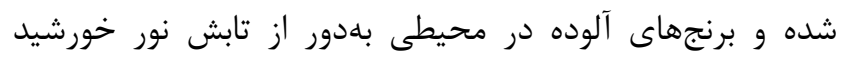

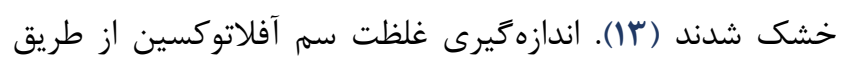

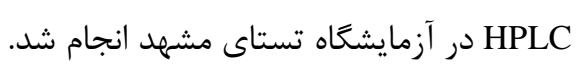

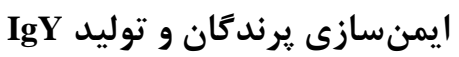

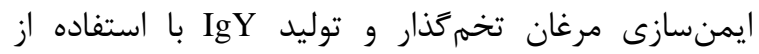

كونزوكَه آفلاتوكسين B1- آلبومين سرم كاوى ( (Sigma) (Conjugate

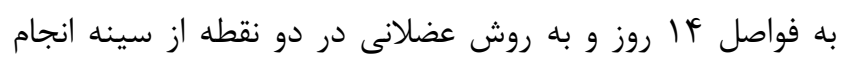

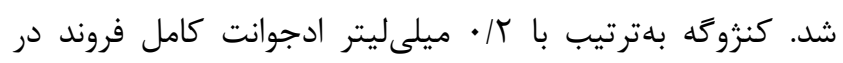

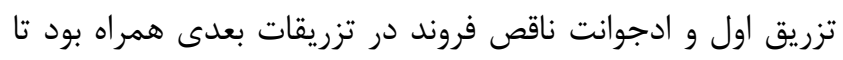

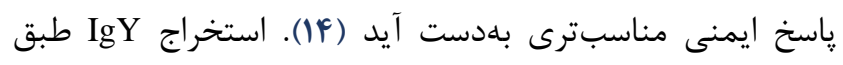

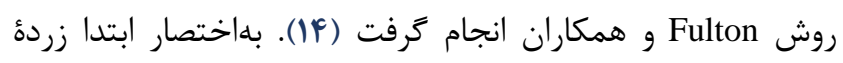

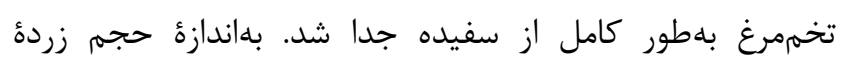

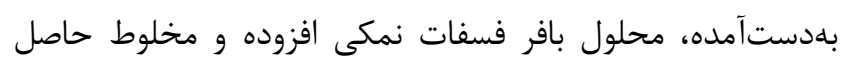

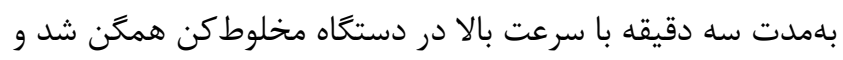

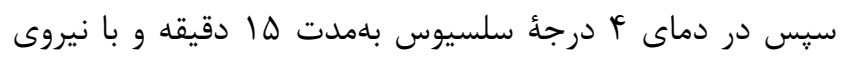

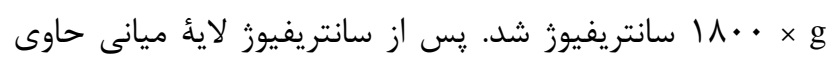

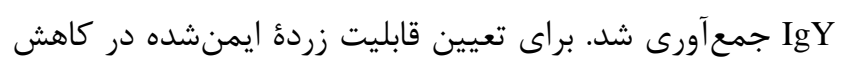

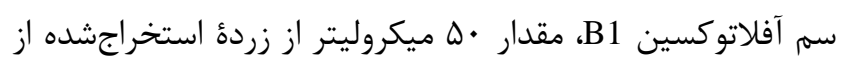

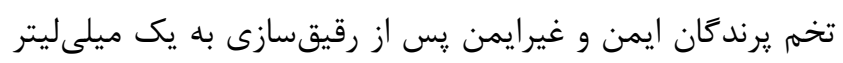

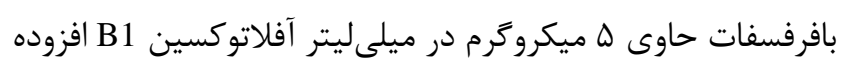

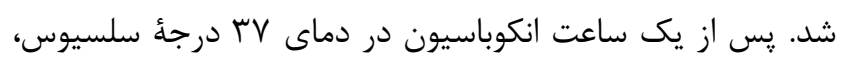

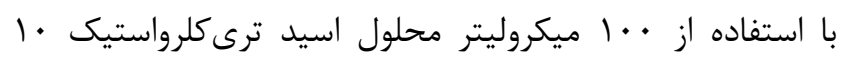

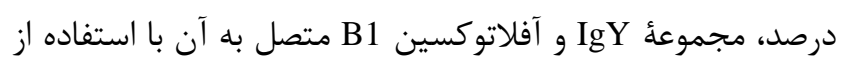

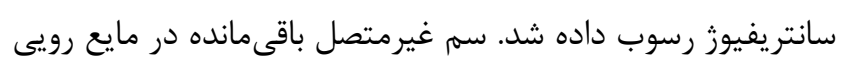

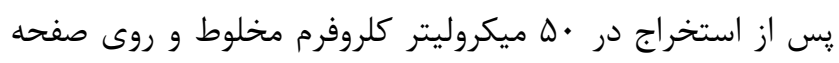
TLC (صفحة آلومينيومى (Thin-layer Chromatography)TLC

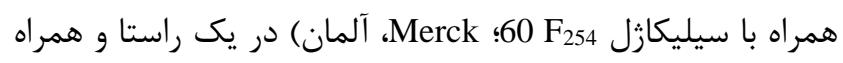
استاندارد سم نقطه كذارى شد. صفحه در يكى بشر محتوى محلول
جستجوى روشهاى مؤثر جايخزين وادار كرده است. بلهتازگى

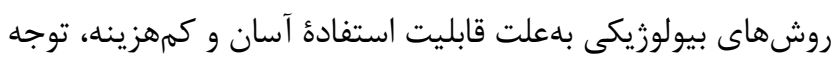

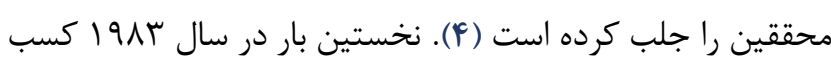

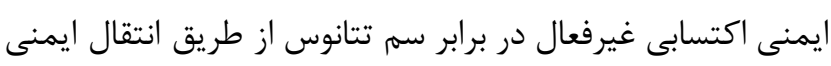

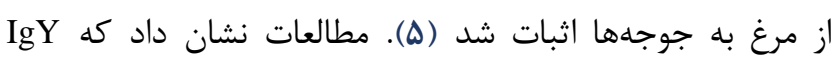

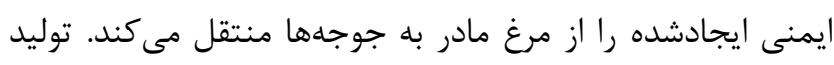

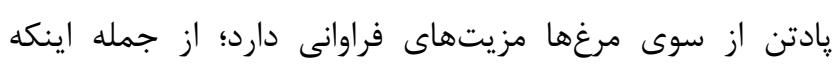

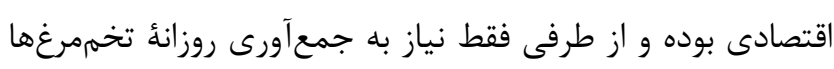
در مقايسه با خون گَيرى از يستانداران دارد.

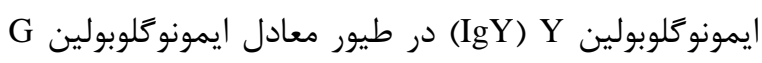

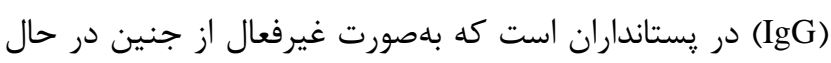

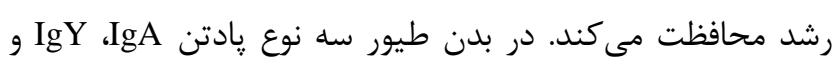

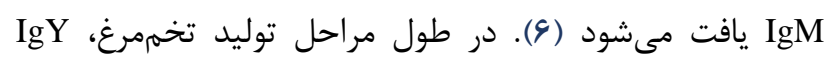

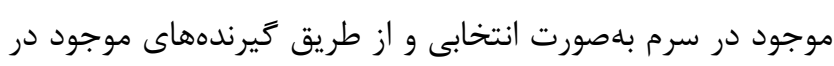

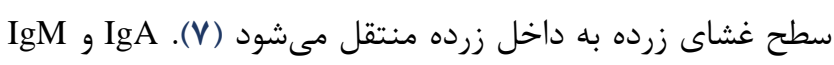

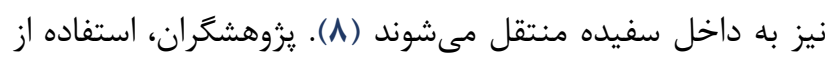

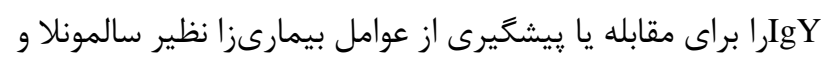

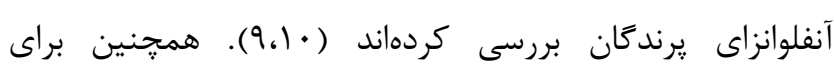

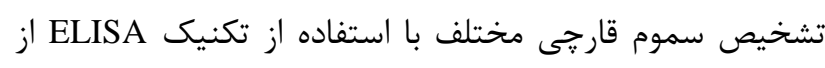

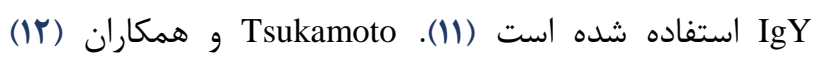

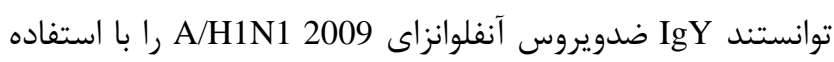

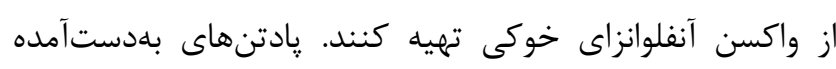

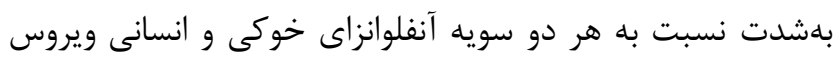

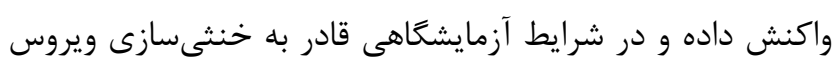
A/H1N1

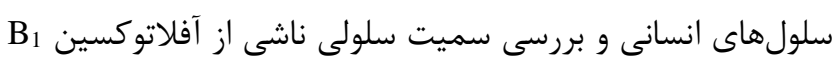

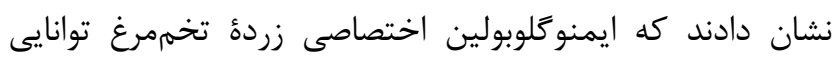

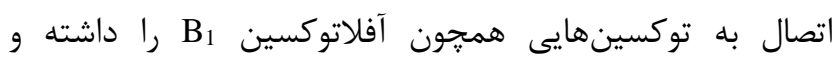

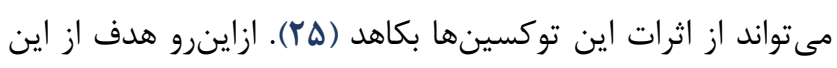

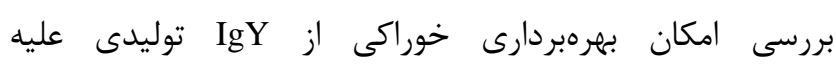

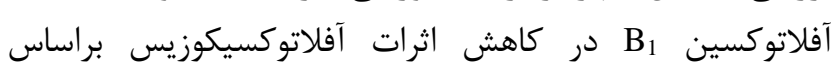

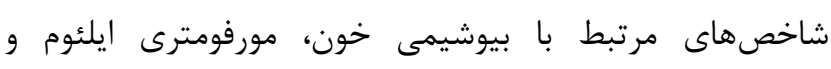

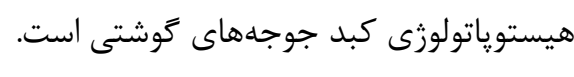

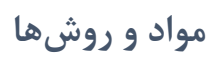
محل انجام آزمايش اين يزوهش در سالن تحقيقاتى واحد داميرورى دانشام انشكدة

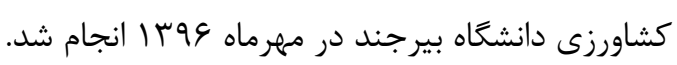


هماتوكسيلين و ائوزين رنخ آميزى شد تا بتوان صفات بافتى را با

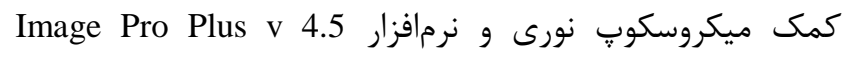

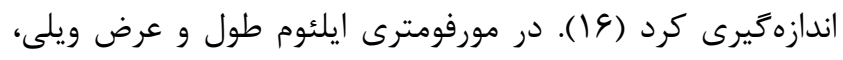

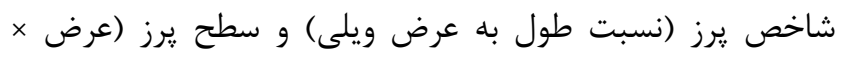

$$
\begin{aligned}
& \text { طول/ ·. . () بررسى شد. } \\
& \text { آناليز آمارى برى }
\end{aligned}
$$

دادههاى حاصل با استفاده از نرمافزار SAS و و روش مارى مدل

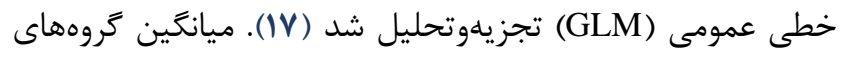

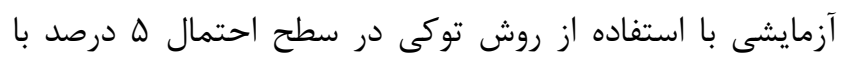
يكديكر مقايسه شدند. بافته ها

\section{غلظت سم توليدى}

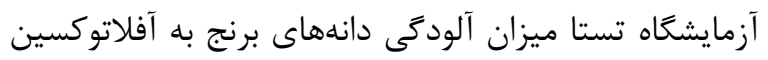

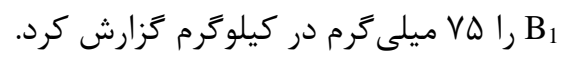

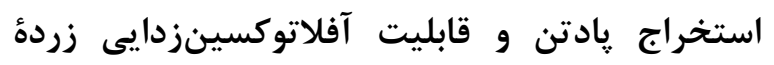

با بررسى صفحات سيليكازل زير نور فلورسنس (شكل ()

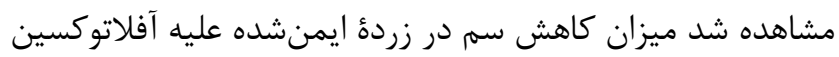

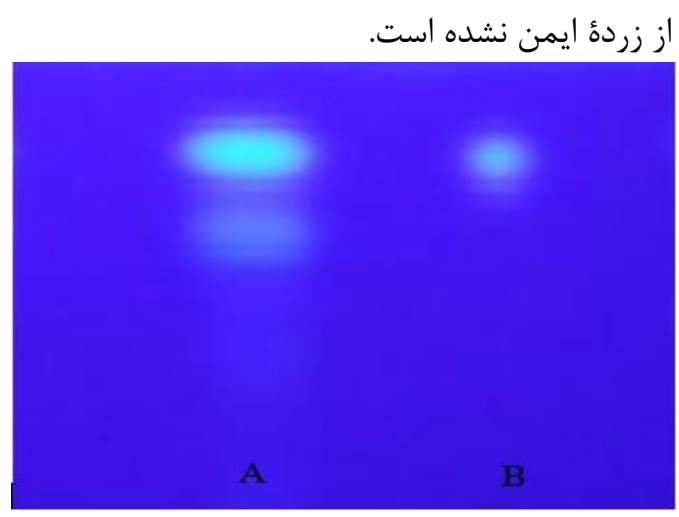

شكل ا. بررسى قابليت زرده ايمنشده در كاهش سم آفلاتوكسين B1

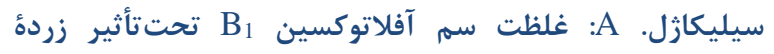

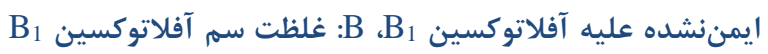

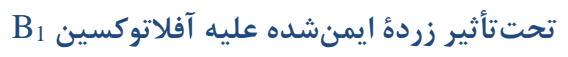

\section{بيوشيميايى سرم خون}

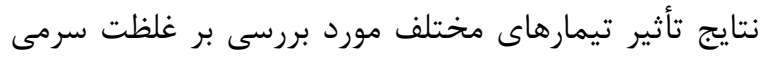

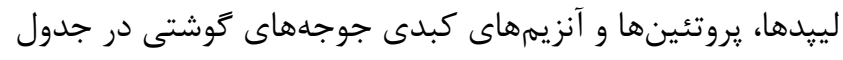

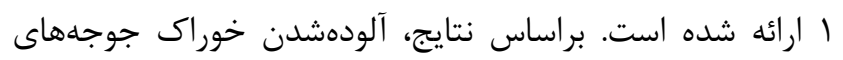

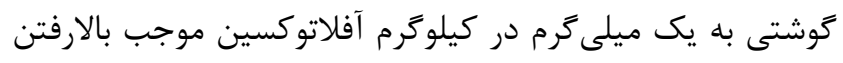

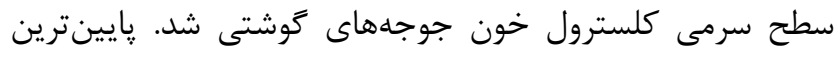

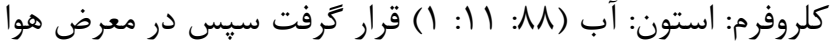

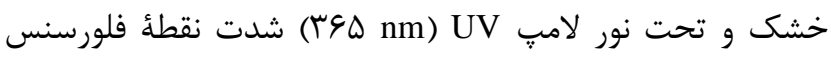

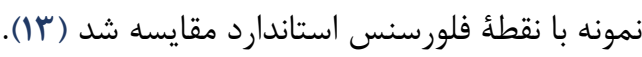

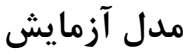

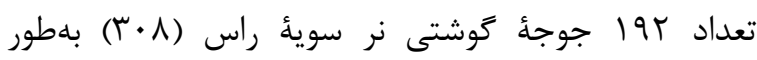

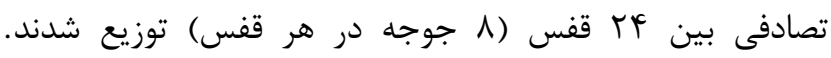

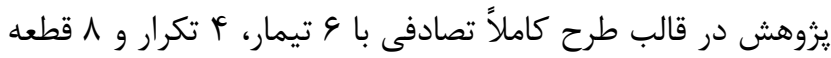

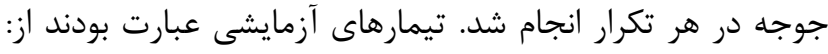

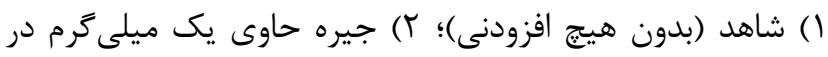

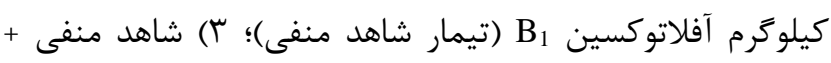

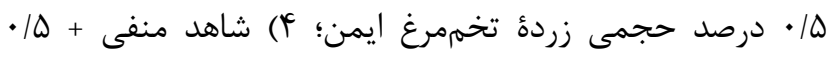

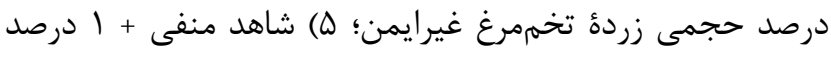

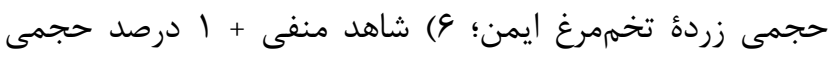

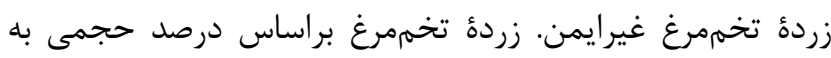

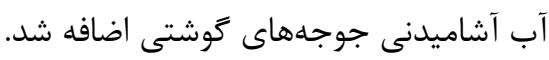

\section{ارزيابى بيوشيميايى سرم خون}

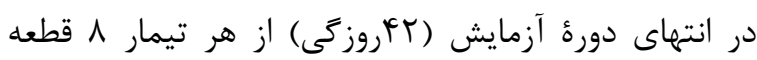

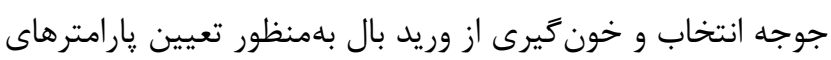

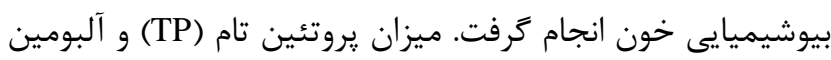
و آنزيمهاى سرم خون از قبيل آسيارتات آمينوترانسفراز (AST)

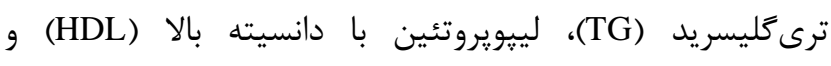

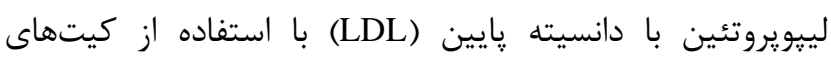

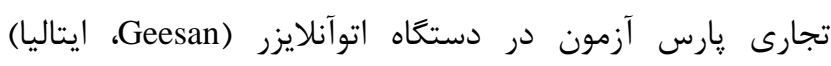

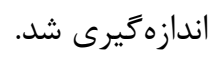

\section{مورفومترى ايلئوم و هيستوياتولوزى كبد}

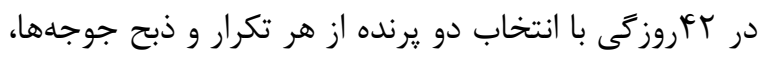

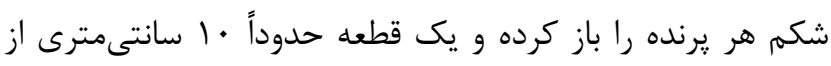

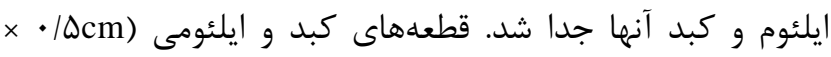

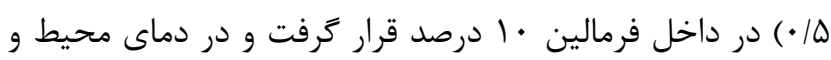

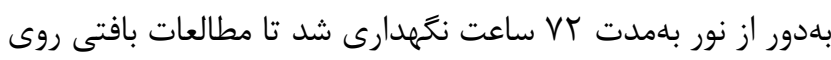

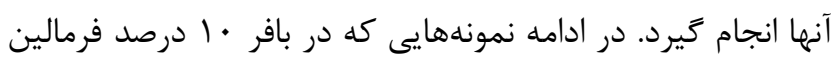

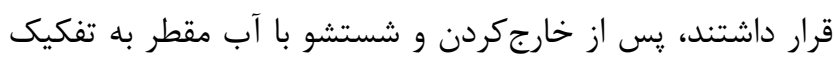

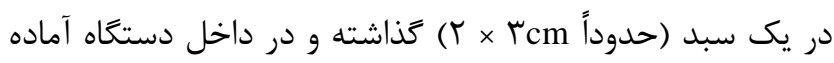

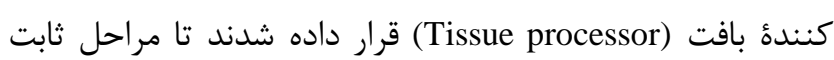

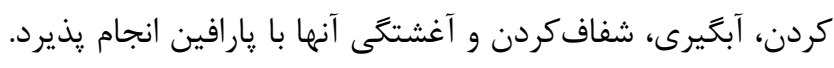

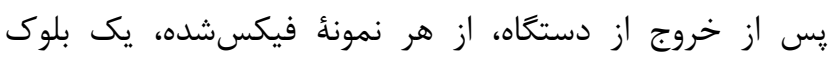

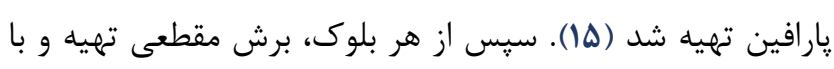


آسيارتات آمينوترانسفراز و گاماكلوبولين ترانسفراز بين تيمارهاى

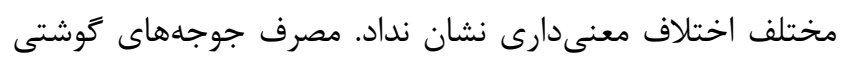
از خوراك تيمار شاهد منفى موجب كاهش غلظت يروتئين تام و

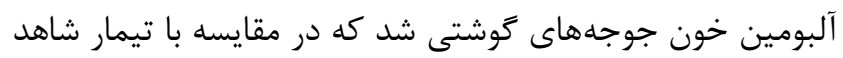

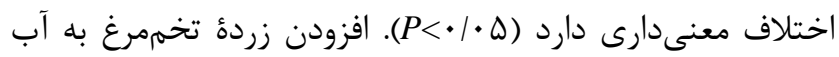
آشاميدنى جوجههاى كوشتى موجب افزايش ميزان بروتئين تام و

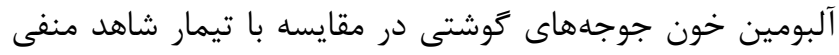
شد. بالاترين غلظت سرمى آلبومين و : يروتئين تام تحت أتأثير

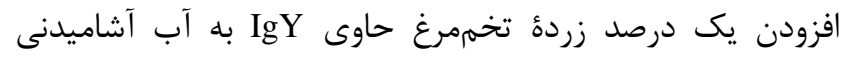

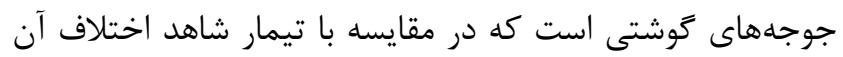

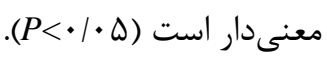

ميزان كلسترول خون جوجههاى گوشتى تحت تأثير افزودن يك درصد زرده تخممرغ فاقد IgY به آب آشاميدنى است كه در دران

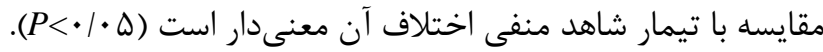
مصرف جوجههاى گوشتى از خوراك تيمار شاهد منفى موجب آنا

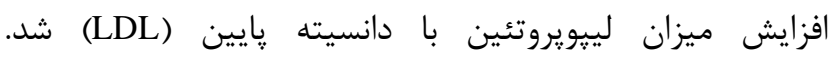
اضافهكردن زرده تخممرغ حاوى و فاقد IgY به آب آشاميدنى جوجههاى تغذيهشده با خوراك آلوده، موجب كاهش ميزان أونان

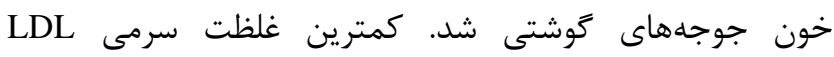

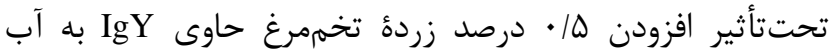
آشاميدنى جوجههاى كوشتى كه در مقايسه با تيمار شاهد منفى آنى

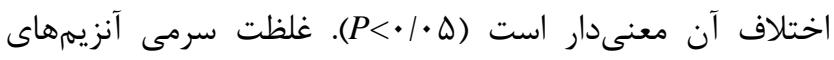

جدول ا. تأثير تيمارهاى مختلف بر غلظت سرمى ليبدها، يروتئينها و آنزيمهاى كبدى (ميلى ترم بر دسى ليتر) جوجههاى كَوشتى در بأروزَى

\begin{tabular}{|c|c|c|c|c|c|c|c|c|}
\hline $\mathbf{T P}$ & GGT & ALB & AST & LDL & HDL & TG & CHOL & تيمارها \\
\hline$r / 9 \cdot{ }^{a}$ & $r F / V \Delta$ & $1 / \Delta \Delta^{a b}$ & & $r T / T \Delta^{\mathrm{ab}}$ & $V F / T \Delta$ & $\Lambda N / T \Delta$ & $\mid r \Psi / r \Delta^{\mathrm{ab}}$ & شاهد \\
\hline l/A & $r \Delta / V \Delta$ & $1 / \pi \varepsilon^{b c}$ & rAT/VD & $\dot{q} \Delta / \ldots^{\mathrm{a}}$ & $\vee \vee / \cdots$ & $q \cdot / r \Delta$ & $\mid \Delta \Delta / \cdots^{a}$ & شاهد منفى \\
\hline$r / r \varphi^{\mathrm{a}}$ & TY/GG & $1 / \Delta r^{a b}$ & rF/T & משr/T b & NוT & $\wedge 9 / \cdot$. & Irf/rrab & ه/ • درصد زرده ايمن \\
\hline $1 / \wedge r^{b}$ & rr/GG & $1 / \pi \omega^{c}$ & $r \Delta \Lambda / \& V$ & $r V / . . b$ & $V 1 / 99$ & $V V / \& V$ & $111 / k r^{b}$ & ه/ • درصد زرده غيرايمن \\
\hline$r / 9 \varphi^{a}$ & rD/rT & $1 / V \cdot a$ & rVI/Q. & $r \cdot / \cdot{ }^{a b}$ & $\vee १ / .$. & NV/r & $\mid r \cdot \ldots a b$ & ادرصد زردهٔ ايمن \\
\hline$r / r^{\mathrm{ab}}$ & $r T /$. & $1 / \varphi^{\mathrm{bc}}$ & TFT/GV & $r N / \& g^{\mathrm{ab}}$ & $V T / l G$ & $\wedge \varepsilon /$. & b س & ا درصد زردهُ غيرايمن \\
\hline$\cdot 1 \cdot \cdots 9$ & - MGta & $\cdot 1 \cdot \cdot \Delta$ & - ITEKT & $\cdot \cdot \Delta \Delta \Delta$ & $.1 .9 \Lambda$. & |TMTI & $\cdot 1 \cdot 9$ & سطح معنىدارى \\
\hline$\cdot / 11$ & $1 / \pi \Delta$ & $\cdot 1 \cdot 0$ & $r \Delta / V F$ & $\Gamma / \Lambda \Delta$ & $T / T V$ & $1 \cdot / 14$ & V/G & خطاى آزمايشى \\
\hline $1 \cdot 119$ & $1 \cdot / \pi$ & $V / q$. & $10 / 19$ & TF/GT & GITT & TF/FT & $|r /|$. & انحرافمعيار \\
\hline
\end{tabular}

منفى (تيمار Y) اختلاف معنى دارى دارد (ه •/•P(P). شاخص يرز و سطح يرز در جوجههاى تغذيهشده با يك ميلى

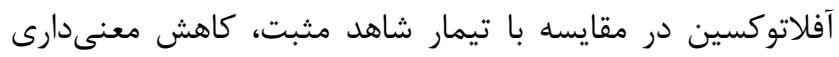

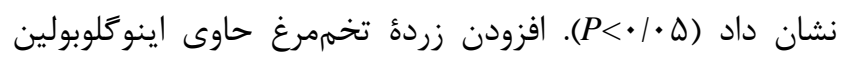

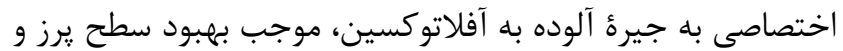
شاخص يرز ايلئوم جوجههاى كوشتى شد (ه •/•P).

\section{هيستوياتولوزى كبد}

فتومورفوَراف آسيبشناسى بافتى كبد طيور تحت تأثير

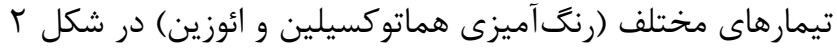

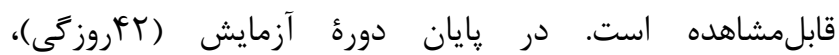
آسيبشناسى بافتى كبد طيور دريافت كنندئ جيرههاى آلودهشده با سم آفلاتوكسين نشاندهندة نفوذ سلولهاى مونونوكلئار

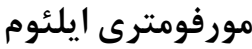

تأثير تيمارهاى مختلف بر مورفومترى ايلئوم جوجههاى كوشتى در جدول r ارائه شده است. كمترين طول ويلى در

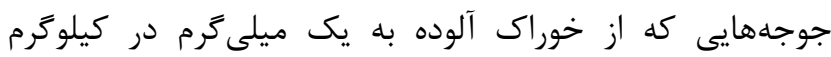
آفلاتوكسين تغذيه شدند، اختلاف معنى دارى با تيمار شاهد مثبت دارد (ه •|•>P). افزودن زرده تخممرغ به آب آشاميدنى جوجههاى كوشتى موجب افزايش طول ويلى ايلئوم جوجههاى كوشتى شد شدرد

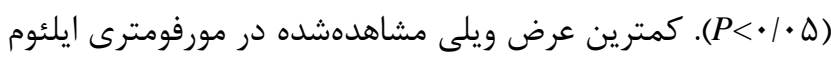
جوجههاى كوشتى تحت تأثير افزودن يك ميلى كرم در كيلوكرم

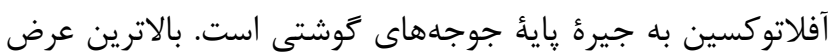

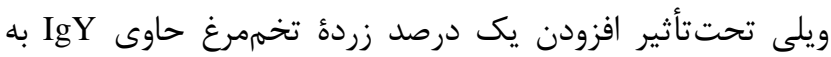

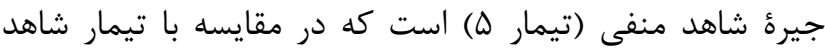


سطوح زرده تخممرغ حاوى ايمنوكلوبولين اختصاصى تقريباً نرمال

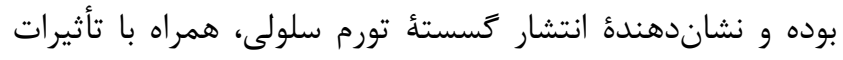

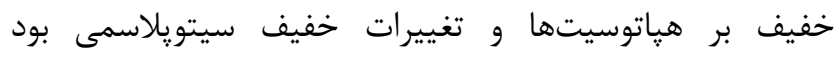
(نواحى كى كه با نوك پِيكان مشخص شده است).
در نواحى يورتال، تكثير غيرمجارى صفراوى، (Mononuclear)

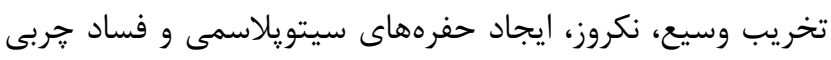

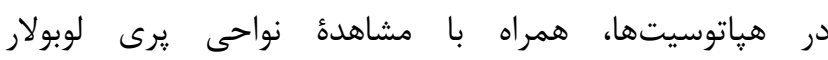

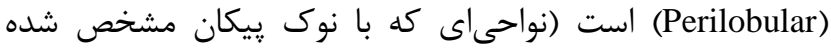

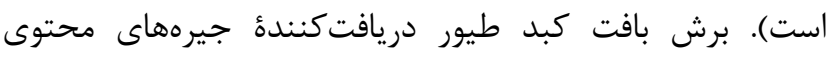

\begin{tabular}{|c|c|c|c|c|}
\hline (ميكرومتر /ميكرومتر) & (ميكرومتر /ميكرومتر ) & $\begin{array}{l}\text { عرض ويلى (ميكرومتر) } \\
\text { (مرو) }\end{array}$ & $\begin{array}{l}\text { (ميكرول ويلى }) \\
\text { (ميكتر) }\end{array}$ & تيمارها \\
\hline$\cdot / r r^{\mathrm{a}}$ & $N / \Delta \Delta^{\mathrm{a}}$ & $\mid 9 \Delta / . . \mathrm{ab}$ & $\mid r q \Delta / .^{a}$ & شاهد \\
\hline$\cdot / 11^{\mathrm{c}}$ & $F / F^{b}$ & $19 r / \Delta \cdot a b$ & sAr/Q $\cdot{ }^{e}$ & شاهد منفى \\
\hline$\cdot / 1 \varepsilon^{b}$ & $\Lambda / 99^{a}$ & $1 f \cdot 1 . . b$ & $\mid r . . . . b c$ & ه/ • درصد زردهٔ ايمن \\
\hline$\cdot / 1 \varepsilon^{b}$ & $r / 9 \Delta^{\mathrm{b}}$ & $19 \cdot 1 .^{a}$ & $\Lambda \wedge \cdot / .^{d}$ & هـ هـرايمن زرده \\
\hline$\cdot / r r^{a}$ & $V / \Delta q^{a}$ & $I V Y / Q \cdot a b$ & $\mid r \wedge \Delta / \ldots a b$ & ادرصد زردهٔ ايمن \\
\hline$\cdot / / \gamma^{b}$ & $9 / 9)^{\mathrm{a}}$ & $\mid \Delta V / \Delta \cdot a b$ & $1 \cdot \wedge \Delta / .^{c}$ & ا درصد زردهٔ غيرايمن \\
\hline$\cdot 1 \cdot \cdots 1$ & $\cdot \mid \cdot \cdot 1$ & $\cdot / . \cdot 9$ & $\cdot \mid \cdot \cdot \cdot$ & سطح معنى دارى \\
\hline $.1 . .90$ & .148 & V/ar & $r 91.0$ & خطاى آزمايشى \\
\hline $1 \cdot / V r$ & $I T / V T$ & १/द & 9194 & انحر افمعيار \\
\hline
\end{tabular}

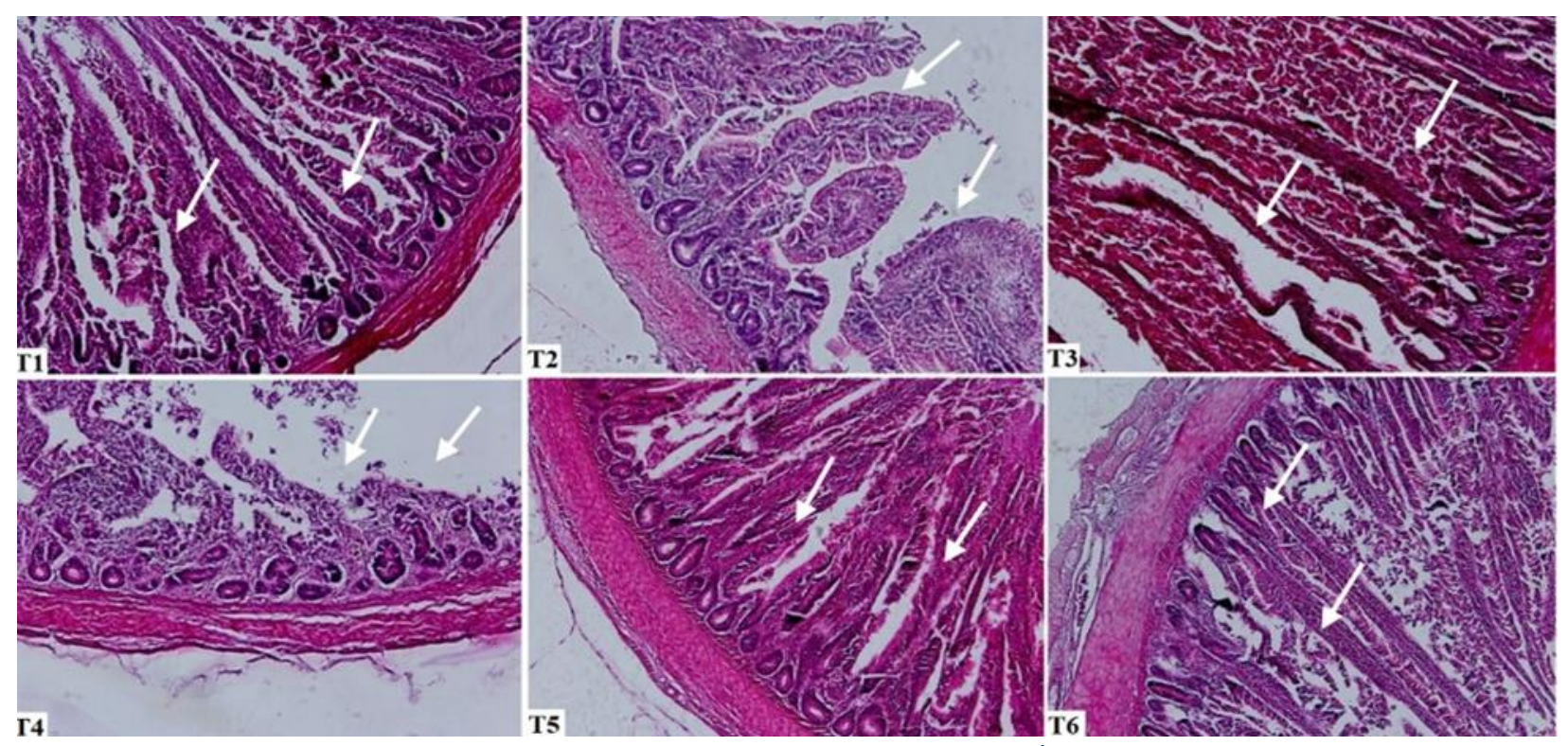

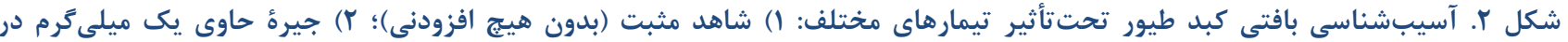

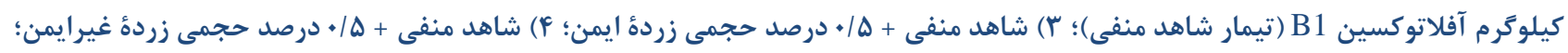

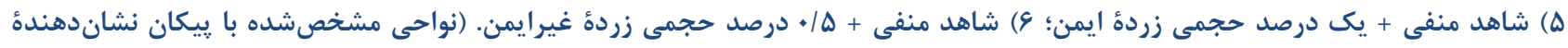

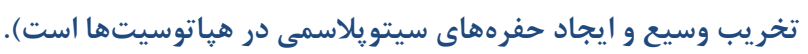


را مهار كرد كه مىتواند بهعلت جذب سم از طريق يادتن موجود

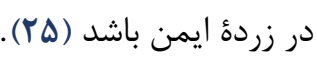
ارتفاع ويلى و نسبت ارتفاع به عمق كرييت در ناحئ ايلئوم جوجههاى كوشتى تغذيهشده با آفلاتوكسين نسبت به كروه شاهد

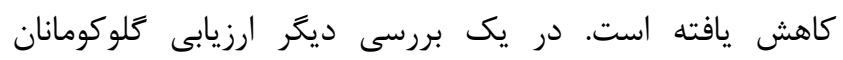

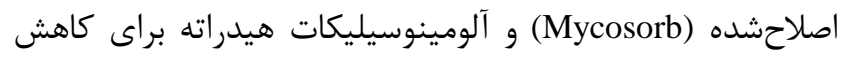

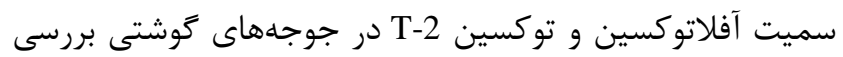

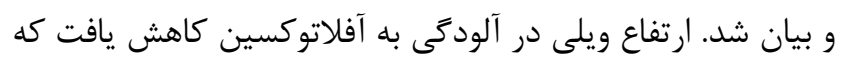

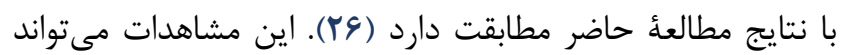

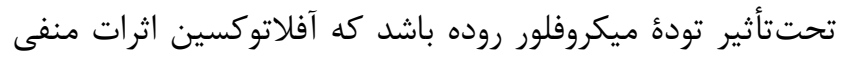

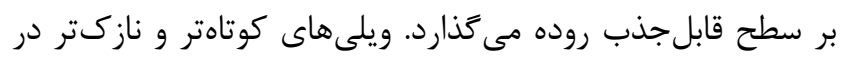

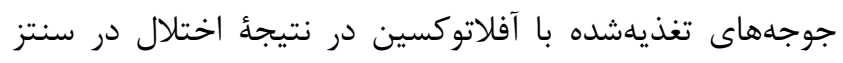

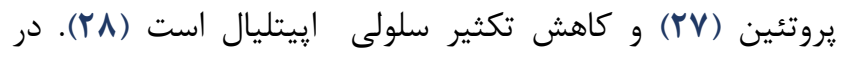

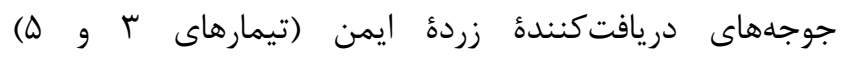

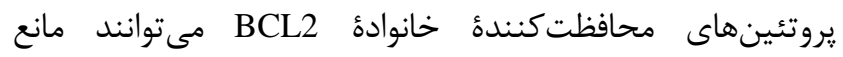

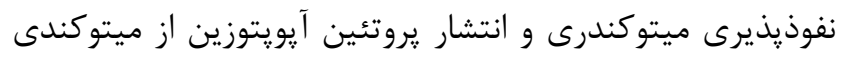

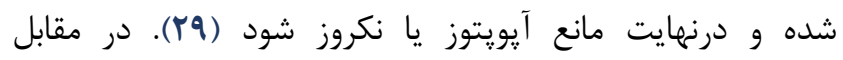

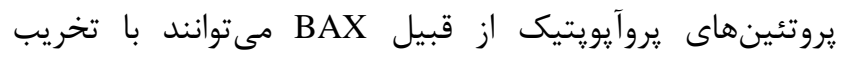

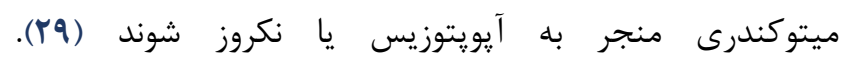

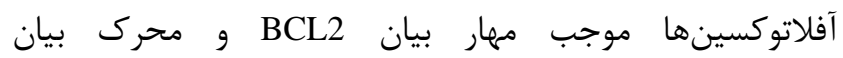
يروتئينهاى BAX هستند (•ب). ايمنوكلوبولين اختصاصى زردهان

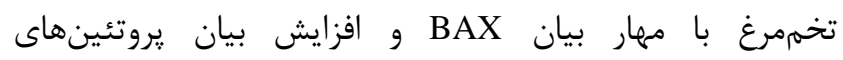

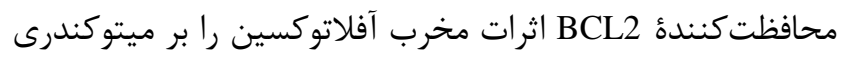
كاهش مى دهد (T)). نتايج تحقيق حاضر با مطالعات

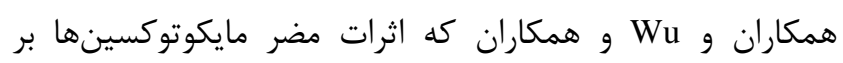

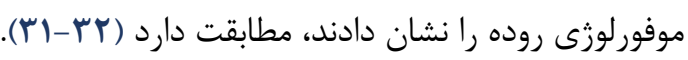

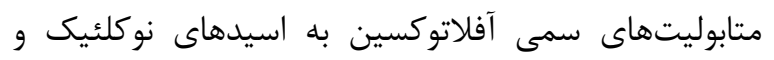

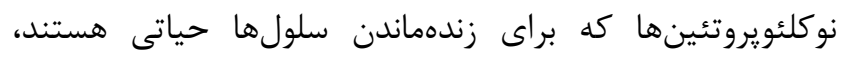

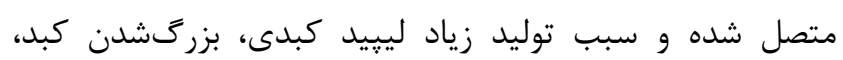

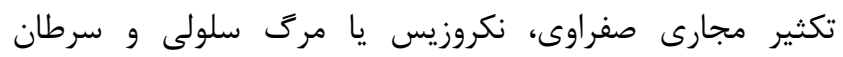

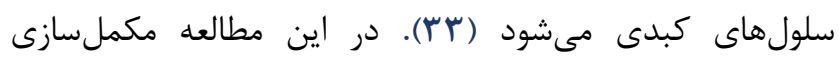

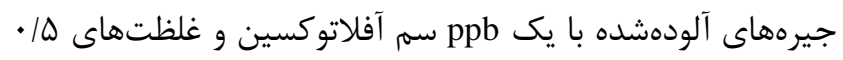

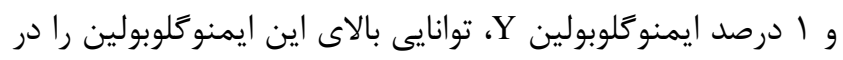

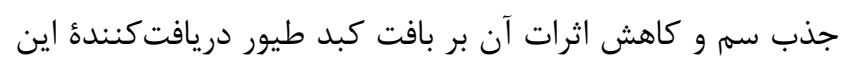

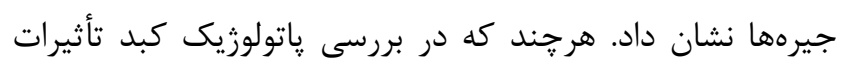

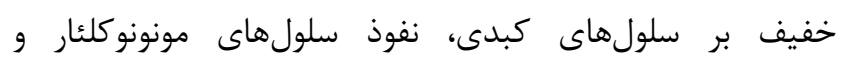
هايير يلازى خفيف صفراوى قابل مشاهده است.
بحث

اندازهخيرى تغييرات بيوشيميايى سرم خون و فعاليت

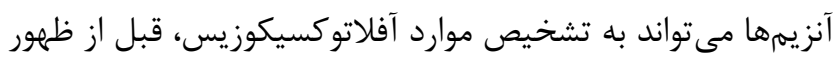
علائم بالينى كمك كند (1)). در تحقيق حاضر تغذيئ جوجهها با موان تيمار شاهد منفى موجب افزايش غلظت سرمى كلسترول و LDL و كاهش غلظت سرمى يروتئين تام و آلبومين شد. همسو با نتايج تحقيق حاضر، در مطالعه Hedayati و همكاران نيز عنوان شد كه در جوجههاى دريافت كننده سم آفلاتوكسين، ميزان كلسترول درول افزايش يافته است (19). كلسترول يكى از استرولهاى اصلى اصلى موجود در همةٔ بافتها بوده كه در هياتوسيتها بيوسنتز مى ئشود.

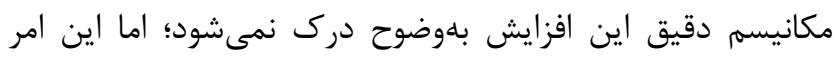

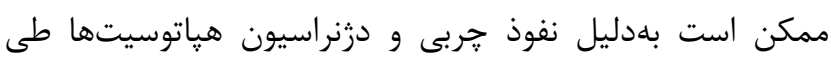

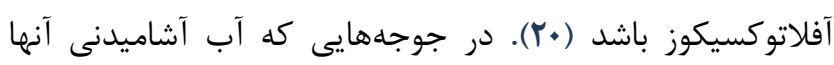
حاوى يك درصد IgY عليه آفلاتوكسين B خون در مقايسه با تيمار شاهد منفى كاهش يافته است. در

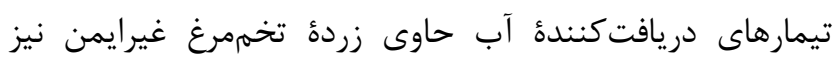
كاهش در مقدار غلظت سرمى كلسترول مشاهده شد كه كاهش اثرات سم از سوى زرده غيرايمن را با توجه به اجزاى سازنده آن

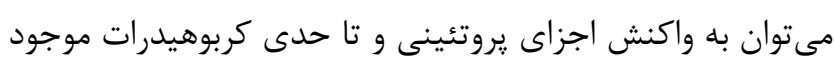

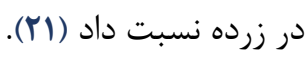

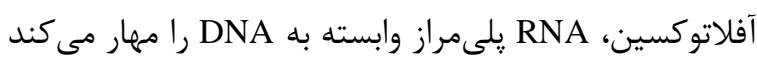
و موجب اختلال در عملكرد DNA هستهاى مىشود كه به مهار كلى توليد يروتئين منتج مى شود (؟). علاوه بر اينها ميزان فعاليت برخى آنزيمها از جمله آسيارتات آمينوترانسفراز و و آلانين آمينوترانسفراز كه براى ترانسآميناسيون اسيدهاى آمينه لازم است، در كبد افزايش يافت. اين موارد حاكى از اين است كه

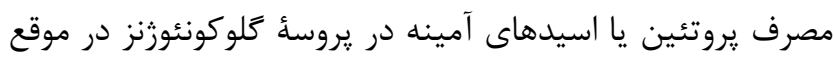

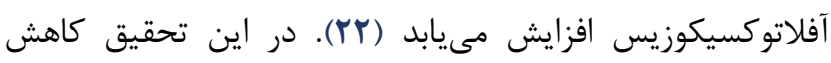
غلظت يروتئين تام خون در جوجههاى تغذيهشده با جيرههاى حاوى آفلاتوكسين، نشانگر اختلال سنتز يروتئين در كبن كبد است

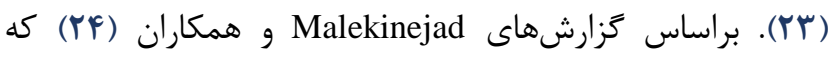
تأثير سطوح مختلف بنتونيت سديم و خارمريم را در جوجههاى كوشتى جالشيافته با آفلاتوكسين B1 مورد بررسى قرار دادند، تيمار شاهد منفى موجب افزايش معنىىدار ترى كليسريد، كلسترول

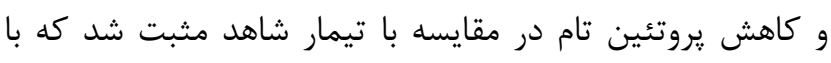

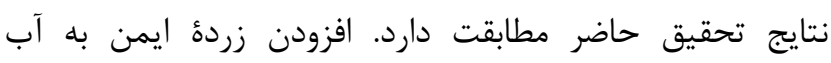

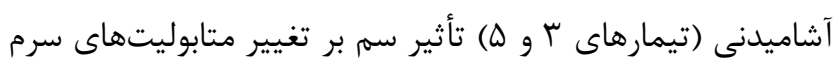


براساس نتايج اين مطالعه، تأثيركذارى زرده در تخممرغهاى ايمن

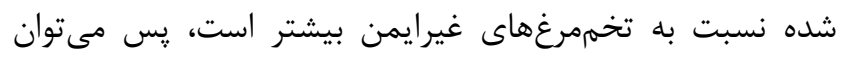

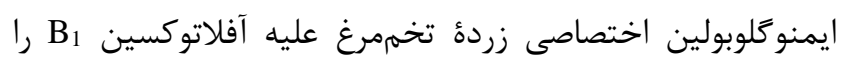

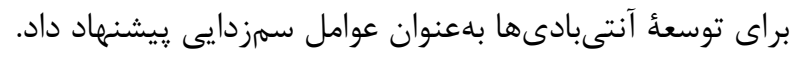

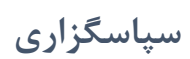

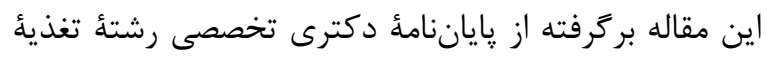

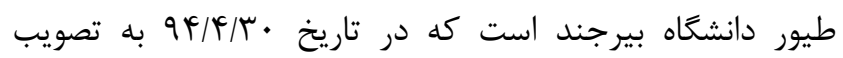

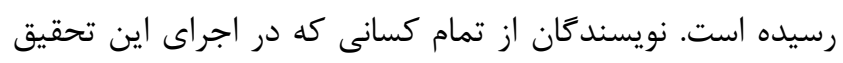

صميمانه يارى رساندهاند، قدردانى مى كنند.

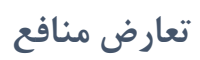

بين نويسندكان تعارض در منافع تزارش نشده است.

\section{References}

1. Edrington T, Kubena L, Harvey R, Rottinghaus G. Influence of a superactivated charcoal on the toxic effects of aflatoxin or T-2 toxin in growing broilers. Poult Sci. 1997;76(9):1205-11. https://doi.org/10.1093/ps/76.9.1205 PMID:9276881

2. Kececi T, Oguz H, Kurtoglu V, Demet O. Effects of polyvinylpolypyrrolidone, synthetic zeolite and bentonite on serum biochemical and haematological characters of broiler chickens during aflatoxicosis. $\mathrm{Br}$ Poult Sci. 1998;39(3):452-8. https://doi.org/10.1080/00071669889051 PMID:9693831

3. Harvey R, Kubena L, Elissalde M, Phillips T. Efficacy of zeolitic ore compounds on the toxicity of aflatoxin to growing broiler chickens. Avian Dis. 1993;37(1):6773. https://doi.org/10.2307/1591459 PMID:8383962

4. Teniola OD, Addo PA, Brost IM, Färber P, Jany KD, Alberts JF, et al. Degradation of aflatoxin B1 by cellfree extracts of Rhodococcus erythropolis and Mycobacterium fluoranthenivorans sp. nov. DSM44556T. Int J Food Microbiol. 2005;105(2):1117. https://doi.org/10.1016/j.ijfoodmicro.2005.05.004 PMID: 16061299

5. Klemperer F. Ueber natürliche Immunität und ihre Verwerthung für die Immunisirungstherapie. Arch Exp Pathol Pharmakol. 1893;31(4-5):356-82. https://link.springer.com/article/10.1007/BF01832882

6. Leslie GA, Martin LN. Studies on the Secretory Immunologic System of Fowl: III. Serum and Secretory IgA of the Chicken. J Immunol. 1973;110(1):1-9. PMID: $\underline{4631071}$

7. Tesar DB, Cheung EJ, Bjorkman PJ. The chicken yolk sac IgY receptor, a mammalian mannose receptor family member, transcytoses $\operatorname{IgY}$ across polarized epithelial cells. Mol Biol Cell. 2008;19(4):1587-93.

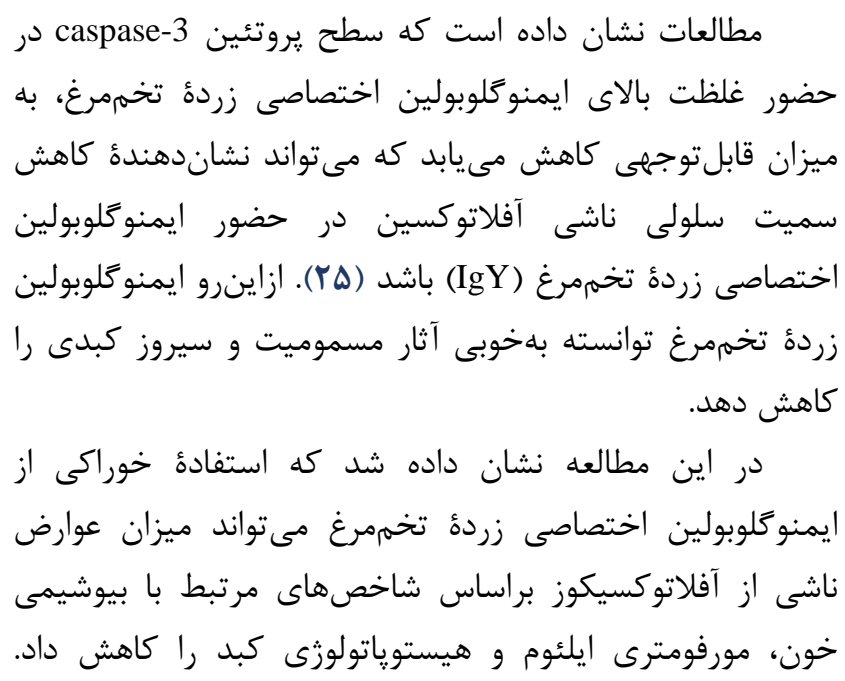

https://doi.org/10.1091/mbc.e07-09-0972

PMID:18256279 PMCID:PMC2291411

8. Rose ME, Orlans E, Buttress N. Immunoglobulin classes in the hen's egg: their segregation in yolk and white. Eur J Immunol. 1974;4(7):521-3. https://doi.org/10.1002/eji.1830040715 PMID:4213170

9. Chalghoumi R, Beckers Y, Portetelle D, Théwis A. hen egg yolk antibodies (IgY), production and use for passive immunization against bacterial enteric infections in chicken: a reviewe. Biotechnol Agron Soc Environ. 2009;13(2):295-308. http://www.pressesagro.be/base/text/v13n2/295.pdf

10. Rahimi S, Shiraz ZM, Salehi TZ, Torshizi MAK, Grimes JL. Prevention of Salmonella infection in poultry by specific egg-derived antibody. Int J Poult Sci. 2007;6(4):230-5. https://doi.org/10.3923/ijps.2007.230.235

11. Lee E, Sunwoo H, Menninen K, Sim J. In vitro studies of chicken egg yolk antibody (IgY) against Salmonella enteritidis and Salmonella typhimurium. Poult Sci. 2002;81(5):632-41. https://doi.org/10.1093/ps/81.5.632 PMID: 12033412

12. Tsukamoto M, Hiroi S, Adachi K, Kato H, Inai M, Konishi I, et al. Antibodies against swine influenza virus neutralize the pandemic influenza virus $\mathrm{A} / \mathrm{H} 1 \mathrm{~N} 1$. Mol Med Rep. 2011;4(2):209-14. https://doi.org/10.3892/mmr.2011.410 PMID:21468553

13. Shotwell OL, Hesseltine C, Stubblefield R, Sorenson W. Production of aflatoxin on rice. Appl Microbiol. 1966;14(3):425-8. PMID:

14. Fulton R, Nersessian B, Reed W. Prevention of Salmonella enteritidis infection in commercial ducklings by oral chicken egg-derived antibody alone or in combination with probiotics. Poult Sci. 2002;81(1):34- 


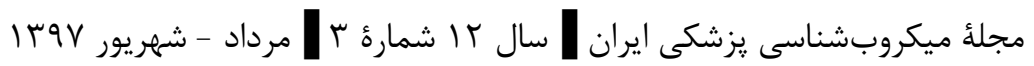

$40 . \quad$ https://doi.org/10.1093/ps/81.1.34

PMID: 11885897

15. Bancroft J, Marilyn G. Theory and practice of histological techniques. 5nd ed. Edinburgh: Churchill Livingstone; 2002.

16. Sakamoto K, Hirose H, Onizuka A, Hayashi M, Futamura N, Kawamura Y, et al. Quantitative study of changes in intestinal morphology and mucus gel on total parenteral nutrition in rats. J Surg Res. 2000;94(2):99$106 . \quad$ https://doi.org/10.1006/jsre.2000.5937 PMID: 11104649

17. Institute S. SAS/GRAPH 9.1 Reference. Jakarta: SAS institute; 2004.

18. Oguz H, Parlat S. Effects of dietary mannanoligosaccharide on performance of Japanese quail affected by aflatoxicosis. S Afr J Anim Sci. 2004;34(3):144-8.

http://dx.doi.org/10.4314/sajas.v34i3.3957

19. Hedayati M, Manafi M, Yari M, Mousavipour S. Commercial broilers exposed to aflatoxin b 1: Efficacy of a commercial mycotoxin binder on internal organ weights, biochemical traits and mortality. Int $\mathbf{J}$ Agric For. 2014;4(5):351-8.

20.Jha A, Shah K, Verma RJ. Aflatoxin-induced biochemical changes in liver of mice and its mitigation by black tea extract. Acta Pol Pharm. 2012;69(5):851-7. PMID:23061280

21. Mine Y. Egg bioscience and biotechnology. New Jersey: John Wiley \& Sons; 2007.

https://doi.org/10.1002/9780470181249

22. van Rensburg CJ, Van Rensburg C, Van Ryssen J, Casey N, Rottinghaus G. In vitro and in vivo assessment of humic acid as an aflatoxin binder in broiler chickens. Poult Sci. 2006;85(9):1576-83. https://doi.org/10.1093/ps/85.9.1576 PMID:16977843

23. Tung $\mathrm{H}$, Wyatt $\mathrm{R}$, Thaxton $\mathrm{P}$, Hamilton $\mathrm{P}$. Concentrations of serum proteins during aflatoxicosis. Toxicol Appl Pharmacol. 1975;34(2):320-6. https://doi.org/10.1016/0041-008X(75)90038-1 PMID: 1209630

24. Malekinejad P, Afzali N, Mohammadi A, Sarir H. Protective effects of milk thistle (silybum marianum) seeds and sodium bentonite in ameliorating the toxic effects of aflatoxin b1 in broiler chicks. Arch Med Lab Sci. 2015;1(2):67-73 http://dx.doi.org/10.22037/amls.v1i2.10292

25. Qiu T, Shen X, Tian Z, Huang R, Li X, Wang J, et al. IgY reduces AFB1-induced cytotoxicity, cellular dysfunction, and genotoxicity in human L-02 hepatocytes and Swan 71 trophoblasts. J Agric Food Chem. 2018;66(6):1543-50. https://doi.org/10.1021/acs.jafc.7b05385

PMID:29325416
26. Girish C, Devegowda G, editors. Evaluation of modified glucomannan (Mycosorb) and hydrated sodium calcium aluminosilicate to ameliorate the individual and combined toxicity of aflatoxin and T-2 toxin in broiler chickens. Proceedings of the 16th Australian Poultry Science Symposium; 2004 Feb 9-11; Sydney, New South Wales, Australia: Poultry Research Foundation; $2004 . \quad$ p.126-9. https://www.cabdirect.org/cabdirect/abstract/200632315 $\underline{56}$

27. Awad WA, Böhm J, Razzazi-Fazeli E, Ghareeb K, Zentek J. Effect of Addition of a Probiotic Microorganism to Broiler Diets Contaminated with Deoxynivalenol on Performance and Histological Alterations of Intestinal Villi of Broiler Chickens. Poult Sci. 2006;85(6):974-9. https://doi.org/10.1093/ps/85.6.974 PMID:16776464

28. Fleming S, Youngman L, Ames B. Intestinal cell proliferation is influenced by intakes of protein and energy, aflatoxin, and Whole-body radiation. Nutr Cancer. 1994;22(1):11-30. https://doi.org/10.1080/01635589409514328 PMID:11304907

29. Cory S, Huang DC, Adams JM. The Bcl-2 family: roles in cell survival and oncogenesis. Oncogene. 2003;22(53):8590-608. https://doi.org/10.1038/sj.onc. 1207102 PMID: 14634621

30. Yang X-J, Lu H-Y, Li Z-Y, Bian Q, Qiu L-L, Li Z, et al. Cytochrome P450 2A13 mediates aflatoxin B1induced cytotoxicity and apoptosis in human bronchial epithelial cells. Toxicol. 2012;300(3):138-48. https://doi.org/10.1016/j.tox.2012.06.010 PMID:22743290

31. Awad W, Ghareeb K, Bohm J, Razzazi E, Hellweg P, Zentek J. The impact of the Fusarium toxin deoxynivalenol (DON) on poultry. Int $\mathbf{J}$ Poult Sci. 2008;7(9):827-42.

https://doi.org/10.3923/ijps.2008.827.842

32. Wu L, Liao P, He L, Ren W, Yin J, Duan J, et al. Growth performance, serum biochemical profile, jejunal morphology, and the expression of nutrients transporter genes in deoxynivalenol (DON)-challenged growing pigs. BMC Vet Res. 2015;11(1):144. https://doi.org/10.1186/s12917-015-0449-y PMID:26138080 PMCID:PMC4490653

33. Bammler TK, Slone DH, Eaton DL. Effects of dietary oltipraz and ethoxyquin on aflatoxin B1 biotransformation in non-human primates. Toxicol Sci. 2000;54(1):30-41. https://doi.org/10.1093/toxsci/54.1.30 PMID: $\underline{10746929}$ 